\title{
ANALISA KEGAGALAN TRACK LINK EXCAVATOR
}

\section{FAILURE ANALYSIS OF TRACK LINK EXCAVATOR}

\author{
Eka Febriyantia, Abdul Gafar ${ }^{\mathrm{b}}$, Agus Suhartono ${ }^{\mathrm{a}}$ \\ aBalai Besar Teknologi Kekuatan Struktur (B2TKS), \\ Badan Pengkajian dan Penerapan Teknologi (BPPT), PUSPIPTEK, Serpong, 16314, Indonesia \\ bInstitut Sains dan Teknologi Nasional (ISTN), Srengseng Sawah-Jagakarsa, Indonesia \\ e-mail:eka.febriyanti@bppt.go.id
}

\begin{abstract}
Abstrak
Track link merupakan salah satu teknologi kunci dalam sistemexcavator selama penggalian dengan beban berlebih. Fungsi dari track link pada excavatoryaitu mengubah gerakan putar menjadi gulungan dan menjadi tumpuan bagi track roller sehingga memungkinkan unit excavator dapat berjalan. Dalam beberapa pemeriksaan di tempat kejadian menunjukkan bahwapin yang merupakan salah satu komponen utama dari track link mengalami patah sehingga menyebabkan excavator berhenti beroperasi. Hasil pemeriksaan visual menunjukkan bahwa pada daerah pin sebagai penyambung antar rantai terjadi retak, dimana retak awal dimulai dari sisi luar dan penjalaran retak dimulai dari material bagian tipis ke tebal. Hasil pemeriksaan tersebut juga dikonfirmasi dengan pemeriksaan metalografi yang menunjukkan adanya inklusi pengotor di lokasi pin yang patah. Oleh karena itu, cacat inklusi akibat proses manufaktur berperan sebagai inisiasi perambatan retak, lalu menjalar akibat pembebanan dinamis dari perputaran track roller sampai akhirnya material pin patah. Analisis kimia dari material pin menunjukkan bahwa material pinyang diperiksa merupakan jenis low alloy steel yang tidak sesuai dengan spesifikasi material standar BS EN 10293 sehingga menyebabkan material pinrentan terhadap serangan korosi setelah retak awal timbul di permukaan akibat pembebanan fatik.
\end{abstract}

Kata kunci :Track Link, Excavator, Inklusi, Beban Dinamis, Korosi

\begin{abstract}
Track link is one ofthe keypaths in the excavatortechnology during excavation with the excess load. Track link's function on the excavator is to convert rotary movements into rolls and become pedestal fortrack roller to allow the excavatorunit to run. In several examinations on site showsthat pin which is one of the main components fromtrack link experienced fracture which causes the excavator to stop operating. The visual examination's results show that in pin area as the interconnecting chain occurs crack where the initial crack starts from the outer side and crack propagation starts from the thinnerside to thicker side material. The result of the visual examination was also confirmed witha metallographic examination which showed inclusion in microstructure at pin's fracture location. Detail analysis of the failed surface showed that failure of the pin on track link excavator is caused by inclusion defect was given by manufacture process whose had a role as crack initiation then propagated by dynamic loading from track roller rotation till pincould not withstand the load and fracture occurred.Chemical analysis indicates that pin material which is examined islow alloy steel type that does not conform to the BS EN 10293 standard specifications so causing the pin materialto be susceptible to corrosion attackafter initial crackarises on the surface due to fatigue loading.
\end{abstract}

\section{KeyWords :Track Link, Excavator,Inclusion, Dynamic Load, Corrosion}

Diterima (received ) : 24 April 2018, Direvisi (revised ) : 26 Oktober 2018, Disetujui (accepted) : 2 November 2018 


\section{PENDAHULUAN}

Selama beberapa dekade terakhir excavator merupakan mesin struktur besar yang di dalamnya terdapattrack link serta bucket wheel yang berperan sebagai teknologi kunci dalam sistemexcavator selama penggalian dengan beban berlebih. Jenis pembebanan pada sistem excavator berupa beban dinamis dan stokastik. Kedua pembebanan tersebut sering menimbulkan kegagalan pada track link excavator ${ }^{1-3)}$. Dalam beberapa kasus dan kondisi pekerjaan yang sangat berat, mobilitas excavator sering mengalami kerusakan akibat mekanisme pengangkutan yang salah ${ }^{4-6)}$ dan struktur7). Kerusakan tersebut dapat disebabkan oleh $^{4-5,8)}$ : cacat desain; cacat manufaktur; cacat pengoperasian; dan cacat lingkungan. Apapun penyebabnya, kerusakan mesin berperforma tinggi menyebabkan kerugian finansial yang sangat besar ${ }^{6,9)}$.

Pada dasarnya, sistem track link excavatorterdiri atas carrier roller, track shoe assembly, idler, track linkassembly, track roller, track shoe, dan sprocket seperti yang terlihat pada Gambar 1.

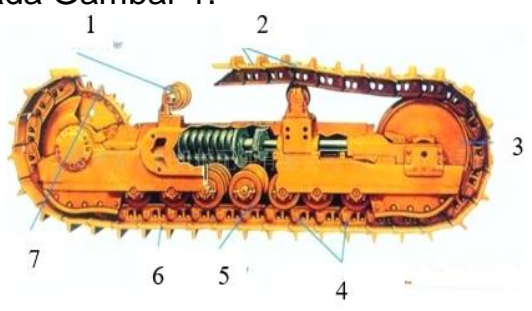

Gambar 1.

Bagian-bagian Excavator Track Link, 10-11)

Keterangan : 1.Carrier roller, 2. Track shoe assembly, 3.Idler, 4. Track link assembly, 5. Track roller, 6. Track shoe, 7.Sprocket

Fungsi dari track link pada excavator ${ }^{6,10-11)}$ yaitu mengubah gerakan putar menjadi gulungan dan menjadi tumpuan bagi track roller sehingga memungkinkan unit dapat berjalan. Komponen-komponen utama track link terdiri atas : link yang berfungsi untuk menumpu berat unit ke landasan dan tempat persinggungan dengan track roller dan carrier roller serta pindan bushing yang berfungsi untuk menghubungkan dan memutuskan antar link sedangkan bushing berfungsi untuk mendapatkan sifat fleksibel ketika track bergerak menggulung. Sedangkan seal berfungsi untuk mencegah terjadinya kebocoran oli dan sebaliknya untuk mencegah agar jangan sampai ada kotoran dari luar yang masuk ke dalam komponen.

Track link pada excavator terdiri atas dua tipe yaitu sealed and lubricated type track dan greased sealed type track. Kemudian track link excavator (Gambar 2) yang retak diuji dan diperiksa di laboratorium supaya akar penyebab kerusakan dapat ditemukan. Hal ini dilakukan untuk mempercepat proses perbaikan dan mencegah terjadinya kerusakan serta kerugian yang sama di pengoperasian selanjutnya.

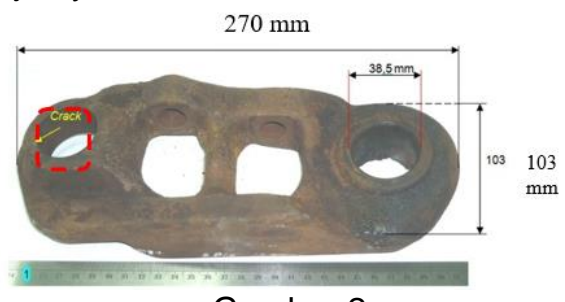

Gambar 2.

Hasil Pengukuran DimensiTrack Link

Excavator yang Mengalami Kerusakan atau Retak pada Daerah Pin

\section{BAHAN DAN METODE}

Metode penelitian terhadap track link excavatoryang mengalami retak dapat dilihat pada Gambar 3 :

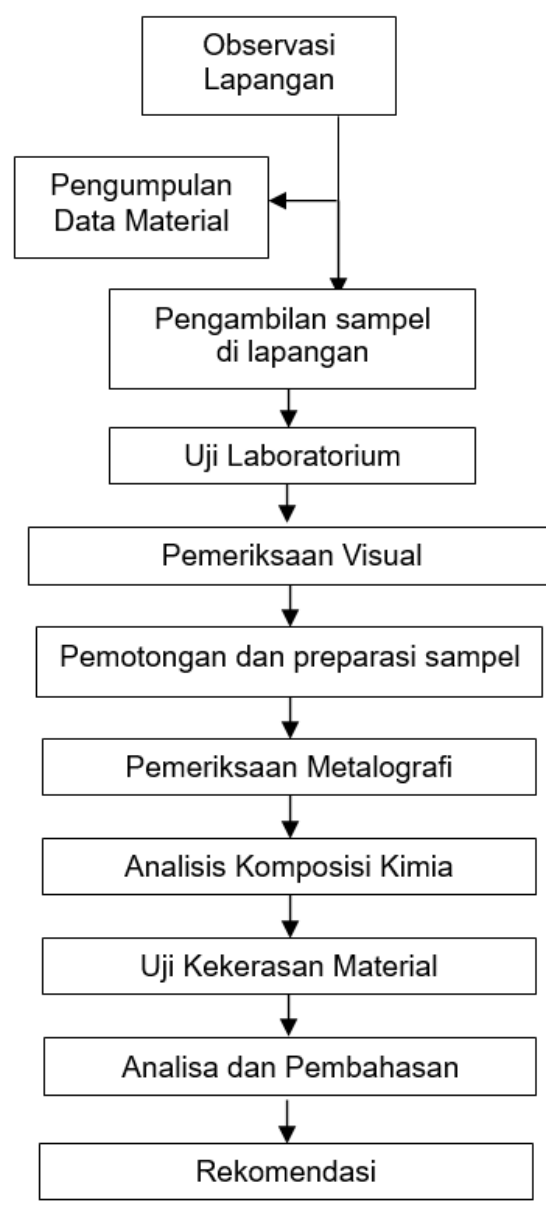

Gambar 3.

Diagram Alir Pemeriksaan dan Pengujian terhadap Pin pada Crack Link Excavatoryang Mengalami Retak 


\section{Hasil Pemeriksaan Visual dan Fraktografi}

Hasil pemeriksaan fraktografi menunjukkan adanya kerusakan/retak pada daerah pin(Gambar 4) sebagai penyambung antar rantai. Selain itu, retak awal dimulai dari sisi luar (Gambar 5) dan penjalaran retak dimulai dari material bagian tipis ke tebal (Gambar 6). Permukaan patahan pada lubang pin berupa patah lelah yang dimulai dari bagian luar. Hal ini dibuktikan dari daerah patah awal yang mempunyai permukaan lebih rata dan adanya initial crack. Sedangkan bentuk alur patah lelah tidak terlihat dikarenakan saat patah kondisi track line excavator mendapat beban operasi sehingga patahan tersebut mengalami benturan antar patahan.

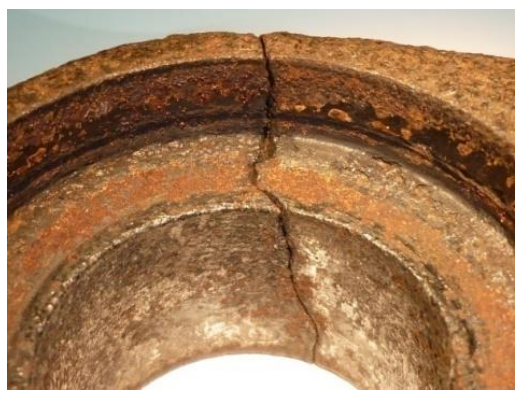

Gambar 4.

Bentuk Retak dari Bagian Dalam Pin

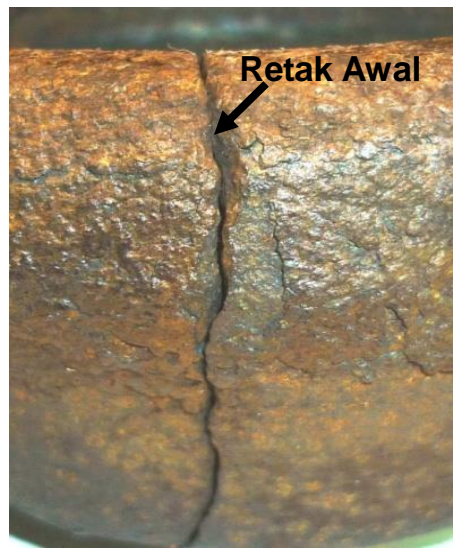

Gambar 5.

Retak Awal Dimulai dari Sisi Luar

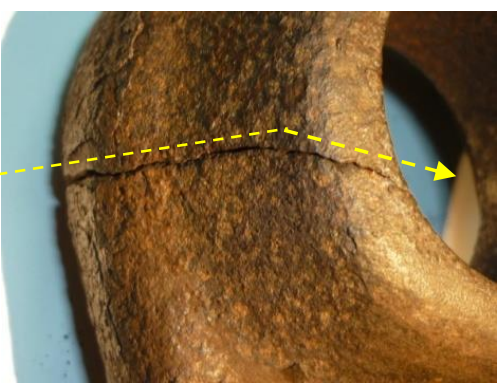

Gambar 6.

Penjalaran Retak Dimulai dari Material Bagian Tipis ke Tebal

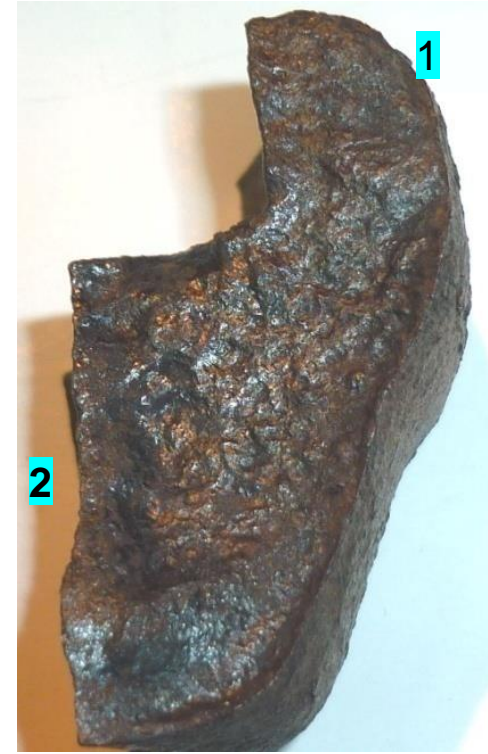

Gambar 7.

Foto Makro Permukaan Patahan pada Lubang Pin

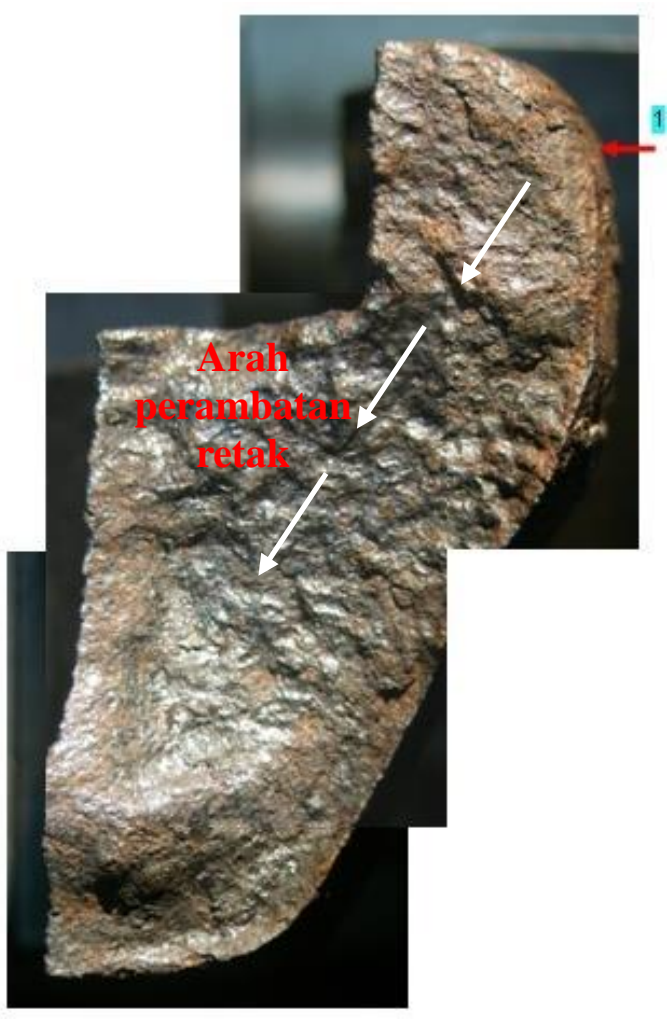

Gambar 8.

Perbesaran Gambar 7 Menunjukkan bahwa Permukaan Patahan pada Lubang Pin Berupa Patah Lelah yang Dimulai dari Bagian Luar (lokasi 1) sedangkan Lokasi 2 Merupakan Patah Akhir 


\section{Hasil Pemeriksaan Metalografi}

Pengambilan foto mikro dan etsa sampel metalografi terdiri atas 2 sampel yaitu sampel 1 di daerah pin sebagai penyambung antar rantai pada bagian luar dan sampel 2 di daerah lubang baut sebagai pembanding.

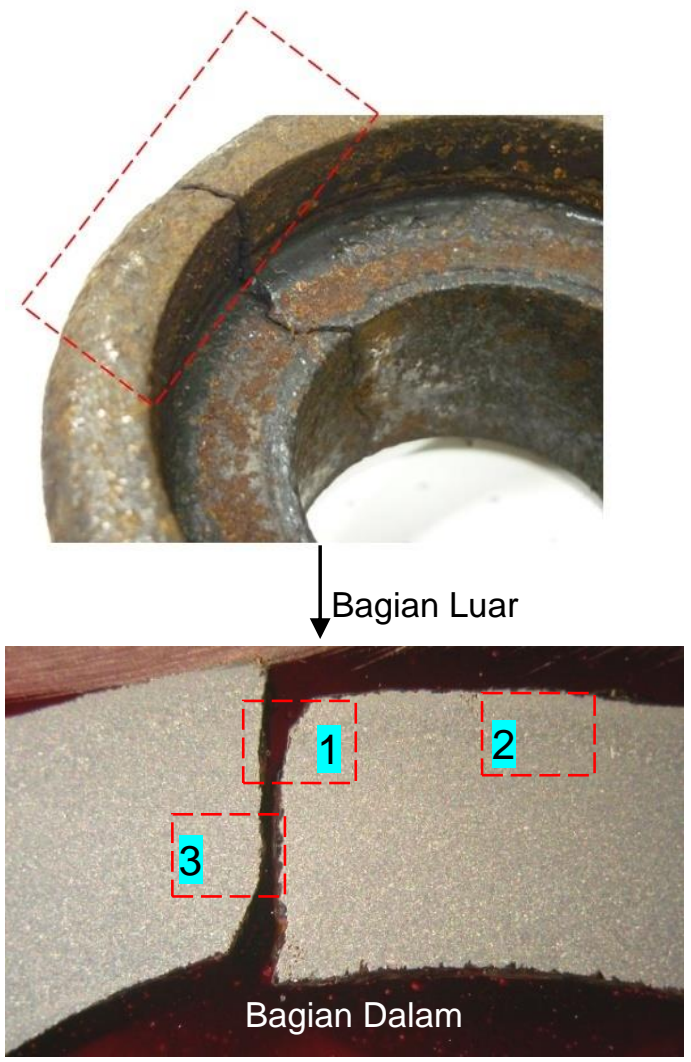

Gambar 9.

Lokasi Pengambilan Sampel 1 Pin pada Track Link Excavatoruntuk Pemeriksaan Metalografi dan Uji Kekerasan

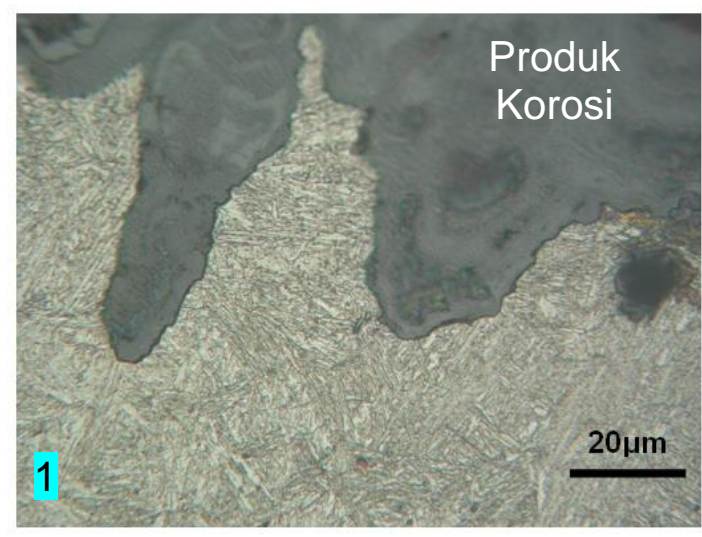

Gambar 10.

Struktur Mikro Sampel 1 padaLokasi 1 di Daerah Awal Retak dari Bagian Luar Berupa Martensit Temper. Selain itu, terjadi korosi merata-sumuran dibagian luar. Etsa : nital 2\%

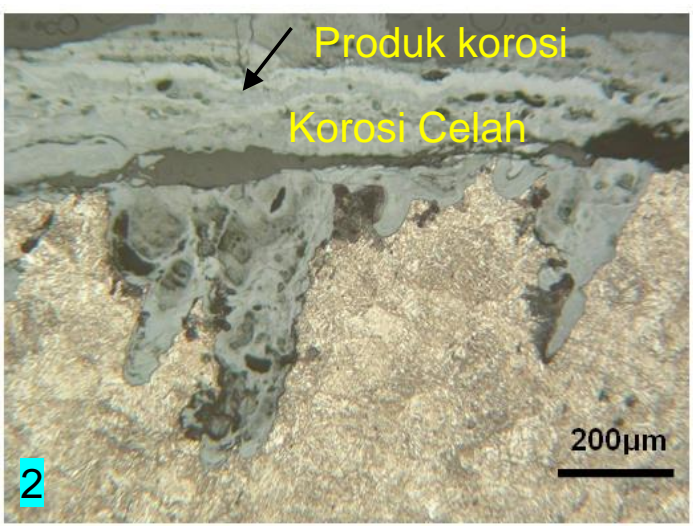

Gambar 11.

Struktur Mikro Permukaan Luar (lokasi 2) berupa Martensit Temperdan Terjadi Korosi Celah. Etsa : nital 2\%

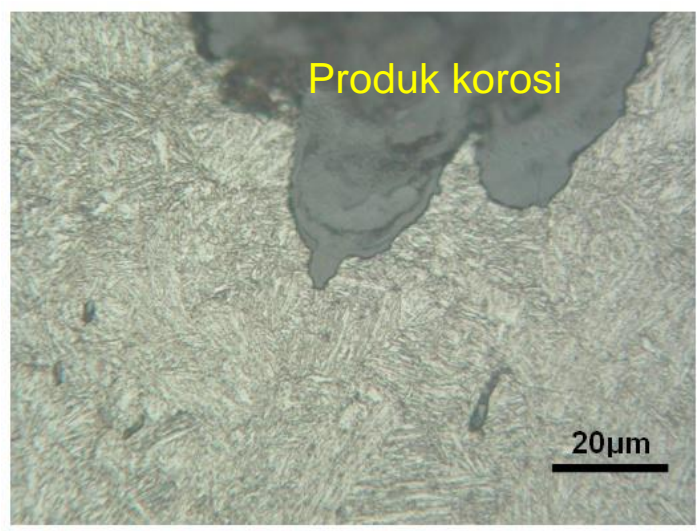

Gambar 12

Perbesaran Gambar 11

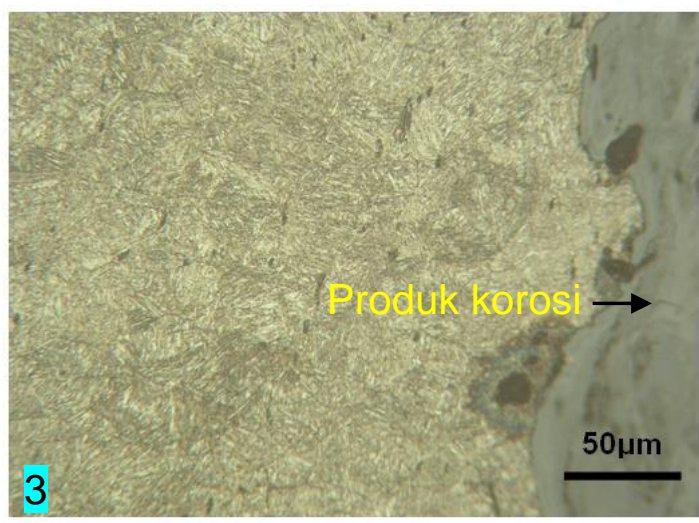

(a) 


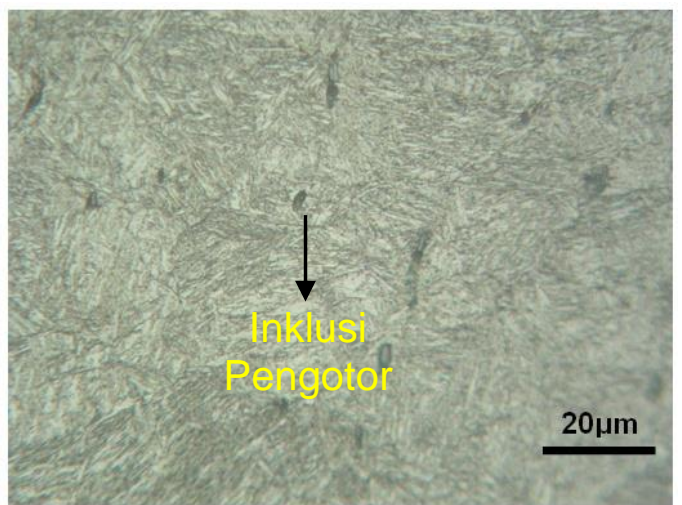

(b)

Gambar 13.

Pada Lokasi 3 Daerah Tengah Patahan Terdapat Produk Korosi, Struktur Mikro Berupa Martensit Temper (a) dan Ditemukan Banyak Inklusi Pengotor(b). Etsa: nital 2\%.
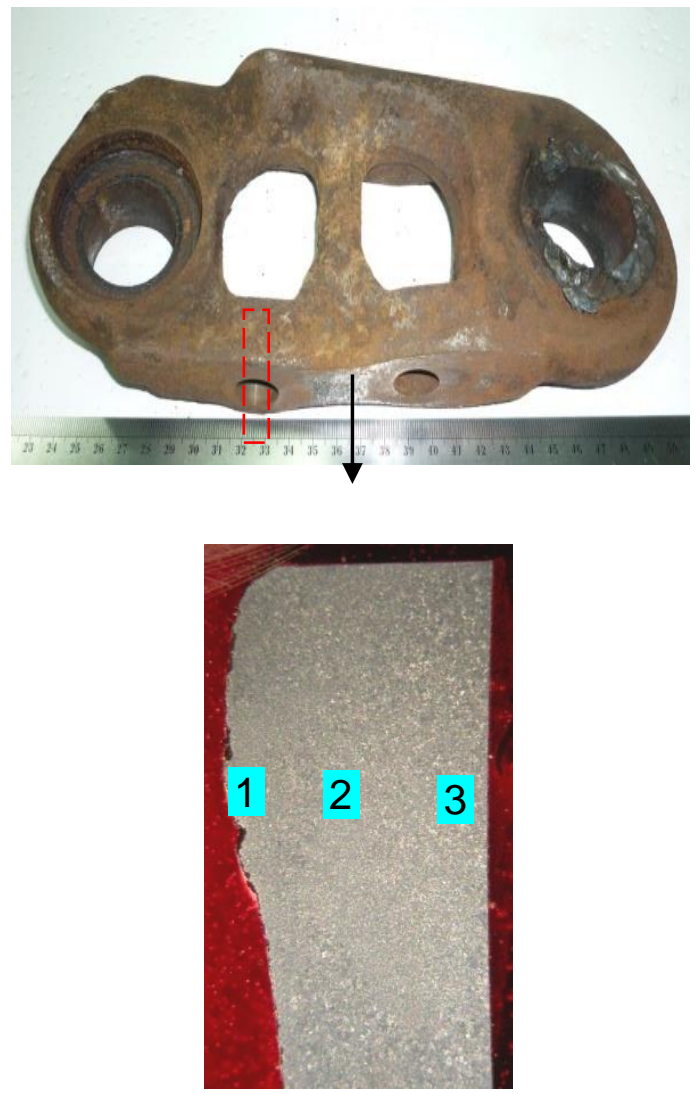

Gambar 14.

Pengambilan Sampel 2 Pin pada Track Link Excavator pada Lubang Baut sebagai

Pembanding
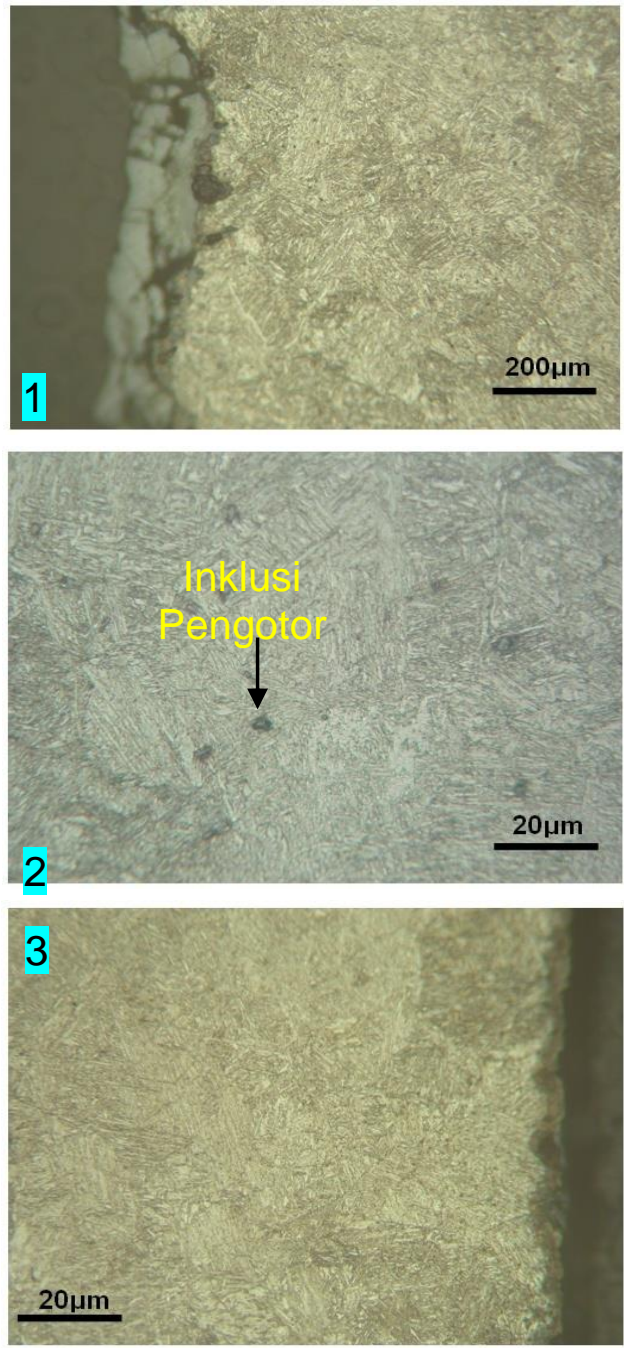

Gambar 15.

Struktur Mikro Sampel 2 Potongan Melintang berupa Martensit Temper dan Terdapat Inklusi

Pengotor. Etsa: nital $2 \%$.

Hasil pemeriksaan metalografi untuk sampel 1 pada lokasi 1 di daerah awal retak menunjukkan bahwa struktur mikro bagian luar berupa martensit temper ${ }^{12)}$. Selain itu, terjadi korosi merata-sumuran di bagian luar seperti yang terlihat pada Gambar 10. Untuk sampel 1 pada lokasi 2 juga menunjukkan bahwa struktur mikro pada permukaan luar berupa martensit temper ${ }^{12)}$ dan terjadi korosi sumuran di bagian luarseperti yang terlihat pada Gambar 11-12. Untuk sampel 1 pada lokasi 3 menunjukkan bahwa struktur mikro pada daerah tengah patahan berupa martensit temper ${ }^{12)}$ serta ditemukan banyak produk korosi dan inklusi pengotor ${ }^{12)}$ seperti yang terlihat pada Gambar 13. Sedangkan untuk sampel 2 menunjukkan bahwa struktur mikro pada potongan melintang berupa martensit temper ${ }^{12)}$ dan ditemukan banyak inklusi pengotor ${ }^{12)}$ seperti yang terlihat pada Gambar 14-15. 


\section{Hasil Analisa Komposisi Kimia}

Sampel untuk analisa komposisi kimia diambil dari track link excavator lalu diuji dengan optical emission spectrometer (OES). Hasil uji menunjukkan bahwa material pin pada track link excavatoryang diperiksa merupakan komposisi kimia low alloy steelseperti yang terlihat pada Tabel 1 .

Hasil analis komposisi kimia menunjukkan bahwa material track link dari excavator tidak sesuai dengan standar BS EN 1029313). Kandungan unsurCr, $\mathrm{Ni}$, dan Mo lebih kecil dibandingkan standar sementara kandungan unsur $S$ lebih tinggi dibandingkan standar.

Tabel 1.

Hasil Uji Komposisi Kimia Pin pada Track Link Excavator

\begin{tabular}{|c|c|c|}
\hline $\begin{array}{l}\text { Unsur / } \\
\text { Elemen }\end{array}$ & $\begin{array}{c}\text { Track } \\
\text { Link } \\
\text { Excavator } \\
\text { (\% berat) }\end{array}$ & $\begin{array}{c}\text { G35 } \\
\text { CrNiMo6-6 } \\
\text { (\% berat) }\end{array}$ \\
\hline $\mathrm{Fe}$ & 97,9 & - \\
\hline $\mathrm{C}$ & 0,373 & $0,32-0,38$ \\
\hline Si & 0,200 & Maks. 0,6 \\
\hline $\mathrm{Mn}$ & $0, \underline{9} 31$ & $0,6-1,0$ \\
\hline $\mathrm{Cr}$ & 0,158 & $1,4-1,7$ \\
\hline $\mathrm{Ni}$ & 0,0755 & $1,4-1,7$ \\
\hline Mo & 0,0323 & $0,15-0,35$ \\
\hline $\mathrm{Cu}$ & $0,15 \overline{4}$ & - \\
\hline Al & 0,0329 & - \\
\hline V & 0,0079 & - \\
\hline W & $<0,025$ & - \\
\hline $\mathrm{Ti}$ & 0,0286 & - \\
\hline $\mathrm{Nb}$ & $<0,003$ & - \\
\hline \multicolumn{3}{|c|}{ B $----<0,001$} \\
\hline$S$ & 0,0214 & Maks. 0,02 \\
\hline$D$ & 0,0143 & Maks. 0,025 \\
\hline
\end{tabular}

\section{Hasil Pengujian Kekerasan}

Hasil uji kekerasan terhadap pin pada track link excavatorterlihat pada Table 2. Hasil uji menunjukkan bahwa untuk permukaan sampel 1 (daerah pin yang retak) dan sampel 2 (lubang baut sebagai pembanding) memiliki nilai kekerasan rata-rata yang hampir sama yaitu masing-masing sebesar 346 HV dan 347 HV.
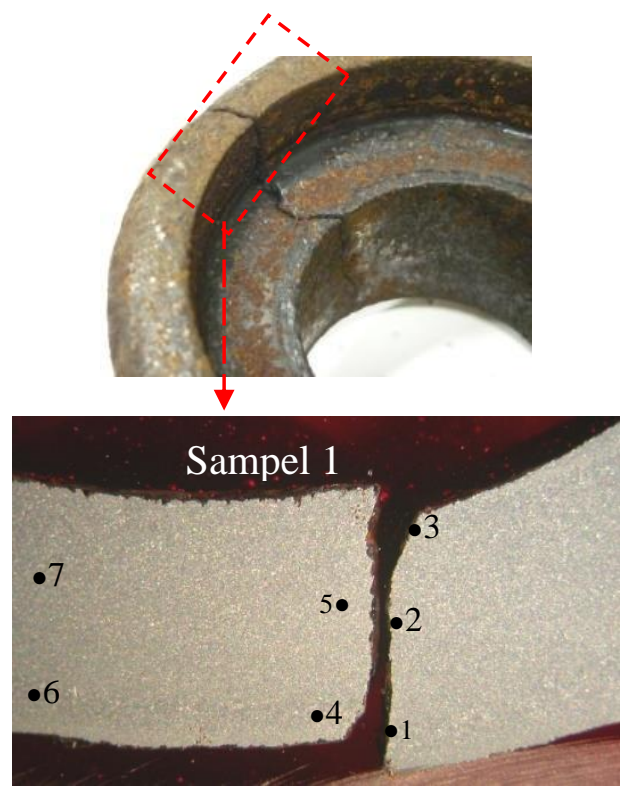

Gambar 16.

Lokasi Pengambilan Sampel 1 untuk Uji Kekerasan
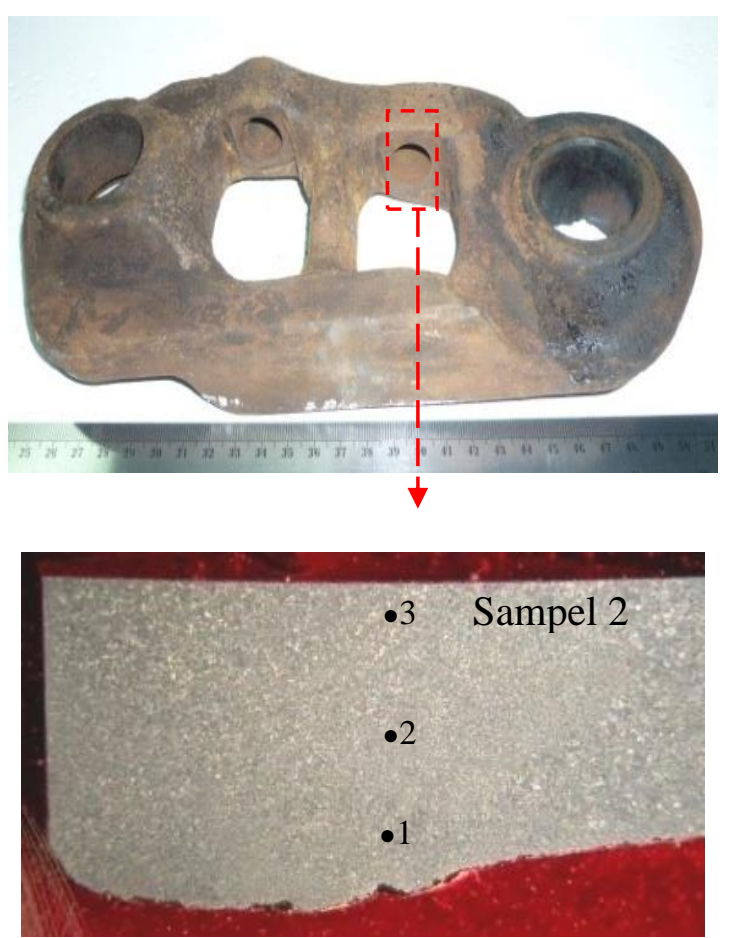

Gambar 17.

Lokasi Pengambilan Sampel 2 untuk Uji Kekerasan 
Tabel 2.

Hasil Uji Kekerasan Pin pada Track Link Excavator

\begin{tabular}{cc}
\hline No. & $\begin{array}{c}\text { Nilai Kekerasan } \\
(\mathbf{H V})\end{array}$ \\
\hline & Sampel 1 \\
1 & 358 \\
2 & 353 \\
3 & 345 \\
4 & 328 \\
5 & 349 \\
6 & 341 \\
7 & 349 \\
Rata-rata & $\mathbf{3 4 6}$ \\
& Sampel 2 \\
1 & 341 \\
2 & 353 \\
3 & 349 \\
Rata-rata & $\mathbf{3 4 7}$ \\
\hline
\end{tabular}

Hasil Analisa SEM dan EDX
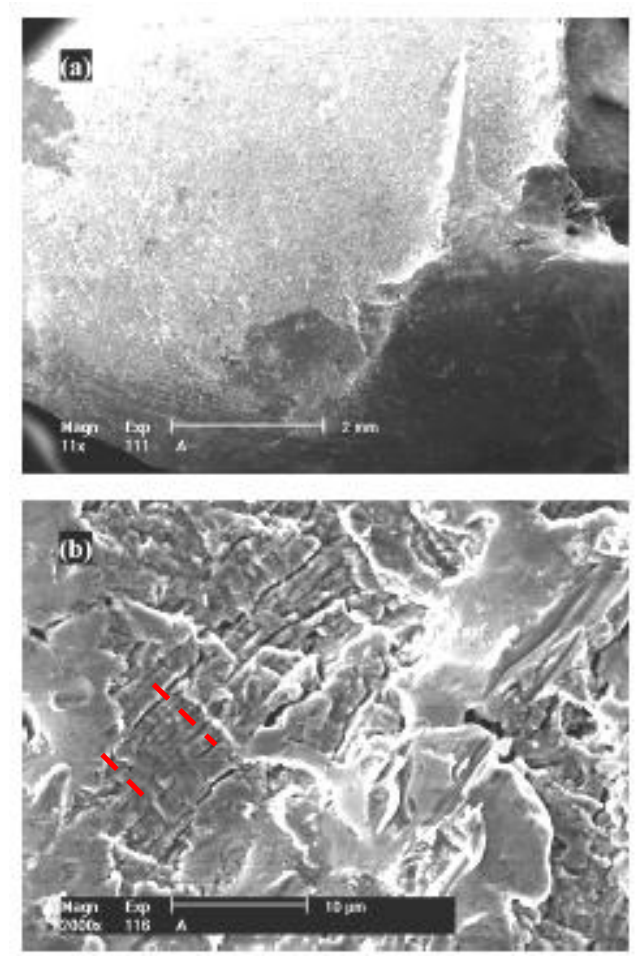

Gambar 18.

Pemeriksaan SEM a) Potongan Melintang Track Link Excavator Menunjukkan Adanya

b) Striasi Fatik

Sampel untuk analisa SEM (Scanning Electron Microscope) diambil dari daerah permukaan patahan track link excavator menunjukkan adanya striasi yang merupakan tipe perambatan retak fatik ${ }^{14)}$ yang terlihat pada gambar 18. Selain itu, pada Gambar 19 menunjukkan adanya inklusi pengotor pada permukaan track link excavator. Sedangkan dari hasil analisa spektrum EDX (Energy Dispersive $X$-ray analysis) dari permukaan patahan track link excavatormengandung unsur-unsur seperti $\mathrm{Fe}$, $\mathrm{Mn}$, dan S seperti yang terlihat pada Gambar 20.

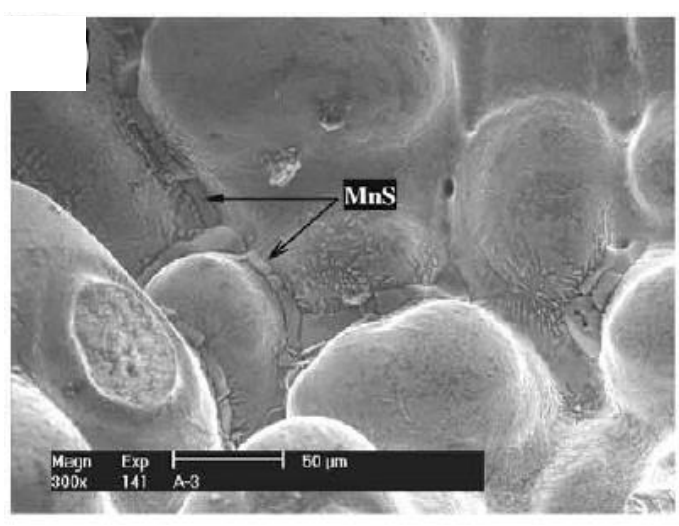

Gambar 19.

Permukaan Patahan Track Link ExcavatorMenunjukkan Adanya Inklusi

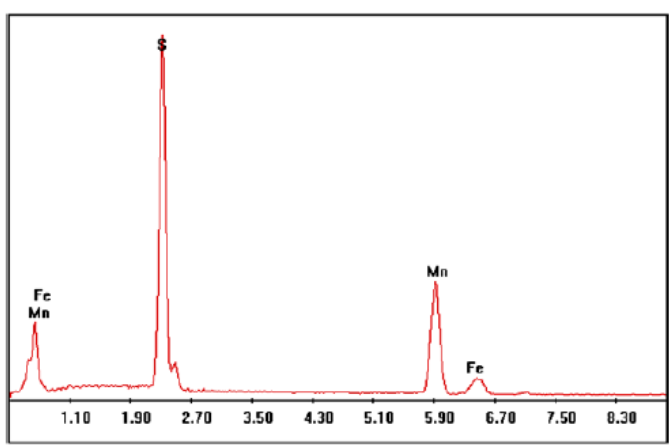

Gambar 20.

Spektrum EDX Inklusi di Permukaan Patahan Track Link Excavator

\section{PEMBAHASAN}

Dari hasil analisa komposisi kimia maka jenis material dan kekerasan pin pada track link excavatortidak sesuai dengan spesifikasi material standar BS EN 10293 seperti yang ditunjukkan pada Tabel 1.

Sedangkan dari hasil pemeriksaan metalografi menunjukkan bahwa mikrostruktur dari material pin terdiri atas martensit temper dan banyak ditemukan inklusi pengotor dan produk korosi seperti yang terlihat pada Gambar 9-15.

Kehadiran inklusi dalam struktur mikro materialpin padatrack link excavator dapat menurunkan kemampuan logam untuk 
menahan beban statik, gaya impak, dan pembebanan fatikyang tinggi14). Inklusi non logam dapat dengan mudah menjadi konsentrasi tegangan ${ }^{14-15}$ karena sifatnya yang tidak terputus dan ketidakcocokan dengan komposisi di sekitarnya ${ }^{16)}$. Inklusi mempunyai sifat berbeda dari matriks (fasa) dalam beberapa aspek seperti perbedaan konstanta elastis (kekakuan yang tidak cocok), perbedaan kekerasan dan kekuatan tarik (kekuatan yang tidak cocok), dan perbedaan koefisien ekspansi (ketidak cocokan ekspansi termal) ${ }^{17)}$. Dari literatur ${ }^{18)}$, koefisien ekspansi beberapa fasa seperti martensit, ferit, dan perlit masing-masing yaitu $11,5 \times 10^{-6} / \mathrm{K} ; 14,8 \times 10^{-6} / \mathrm{K}$; dan $23 \times$ $10^{-6} / \mathrm{K}$, sedangkan koefisien ekspansi dari kehadiran senyawa kalsium aluminat sebesar 5-8,5 x 10-6/K. Hal tersebut menunjukkan bahwa perbedaan koefisien ekspansi antara inklusi dan matriks sangat besar. Medan gaya tarik yang lebih besar akan diproduksi dalam matriks (fasa) di sekitar inklusi kalsium aluminat karena inklusi kalsium aluminat menghasilkan ekspansi volume yang lebih kecil selama periode quenching sampai cooling. Ukuran inklusi yang lebih besar maka tegangan tarik semakin besar17). Awal retak kemungkinan terbesar dimulai dari matriks sekitar kumpulan inklusi di bawah pembebanan gaya eksternal.

Retak awal dimulai dari sisi luar dimana mempunyai permukaan lebih rata dan bersumber di sekitar inklusilalu akibat adanya pembebanan dinamis dari pergerakan excavatorkemudianterjadi perambatan retak yang dimulai dari bagian tipis ke tebal. Namun bentuk alur patah lelah tidak terlihat dikarenakan saat patah kondisi track line excavatomendapat beban operasi sehingga patahan tersebut mengalami benturan antar patahan. Lalu, karena material track link mengandung unsur-unsur seperti $\mathrm{Cr}, \mathrm{Ni}$, dan Mo yang lebih kecil dibandingkan standar[18] dimana kandungan unsur-unsur yang lebih kecil dibandingkan standar menyebabkan ketahanan korosi dari track link menjadi lebih rendah sehingga serangan korosi masuk ke sisi dalam track link yang terbuka akibat adanya retak dari pembebanan fatik.

\section{SIMPULAN}

Dari hasil observasi, pengamatan, dan analisa laboratorium serta pembahasan dapat disimpulkan bahwa penyebab perpatahan track link excavator adalah cacat akibat manufaktur pada material pintrack link berupa inklusi pengotor. Inklusi pengotor berperan sebagai pusat tegangan tinggi (severe stress concentration) yang akan mempengaruhi ketahanan fatik dari track link excavatordan memfasilitasi inisiasi dari perambatan retak fatik. Adanya pembebanan dinamis dari pergerakan menyebabkan material screw mengalami kelebihan tegangan pada daerah tertentu dan akhirnya menghasilkan retak dan patahan.

\section{REKOMENDAS}

Oleh karena karakteristik material lebih rendah dibandingkan yang dibutuhkan (akibat ketidaksesuaian dengan spesifikasi standar dan kesalahan dalam proses manufaktur) maka sebaiknya kinerja dari track link excavator perlu diinspeksi misalnya setiap 1000 jam operasi pengerjaan sehingga apabila terjadi kerusakan/retak awal dapat ditemukan dan segera dilakukan perbaikan.

\section{UCAPAN TERIMA KASIH}

Penulis mengucapkan terima kasih kepada Dr.Ing.H.Agus Suhartono selaku Kepala Bidang Kajian Material B2TKS, untuk koordinasi dan pemberian ijin dalam menggunakan alat uji laboratorium. Selain itu, penulis juga mengucapkan terima kasih kepada teman-teman teknisi di laboratorium analisa kerusakan dan umur sisa karena telah membantu dan memberikan saran ketika pelaksanaan penelitian dan pengujian.

\section{DAFTAR PUSTAKA}

1. Bošnjak S.M., dkk, "Failure Investigation of The Bucket Wheel Excavator Crawler Chain Link", Engineering Failure Analysis, (35) 2013, p.462-469.

2. Dacinic, Darco, dkk, "Bucket Wheel Excavator Damage by Fatigue Fracture ", Procedia Materials Science, (3), 2014, p.1723-1728.

3. Savkovic, Mile, dkk, "Analysis of The Drive Shaft Fracture of The Bucket Wheel Excavator, Engineering Failure Analysis, (20), 2012, p.105-117

4. Dudek, D., dkk, "The L35GSM Cast Steel - Possibilities of Structure and Properties Shaping at The Example Of Crawler Links", Arch. Civ. Mech. Eng., (11),2011, p.19-32.

5. Bošnjak S.M., dkk, "Failure Analysis of The Stacker Crawler Chain Link", Procedia Eng., (10), 2011, p.2244-2249. 
6. Arsic" M., dkk, "Analysis Of The Spreader Track Wheels Premature Damages", Engineering Failure Analysis, (20), 2012, p.118-136.

7. Bošnjak S.M., dkk, "Failure Analysis And Redesign Of The Bucket Wheel Excavator Two-Wheel Bogie", Engineering Failure Analysis, (17), 2010, p.473-485.

8. Bošnjak S.M., dkk, "Failure Investigation Of The Bucket Wheel Excavator Crawler Chain Link", Engineering Failure Analysis, (35), 2013, p.462-469.

9. Bošnjak S.M., dkk,"Bucket Wheel Excavator: Integrity Assessment Of The Bucket Wheel Boom Tie - Rod Welded Joint", Engineering Failure Analysis, (18), 2011, p.212-222.

10. Sokolski, P., dan M. Sokolski, "Evaluation of Resistance to Catasrophic Failures of Large-Size Caterpillar Chain Links of Open-Pit Mining Machinery", Maintenance and Reliability,(16) (10), 2014, p.80-84.

11. Maulana, Irfan, dkk "Analisa Kerusakan Komponen Under carriage Excavator Hitachi EX200 Pada PT. Takabeyaka Perkasa Group dengan Metode FMEA", Jurnal Mesin Sains Terapan,(1) (1),2017, p.32-38.
12. $\mathrm{Yu}, \mathrm{Zhi}-\mathrm{Wei}$, dkk, "Failure Investigation on The Cracked Crawler Pad Link", Eng. Fail. Anal., (17), 2010, p.1102-1109

13. Steel Casting Chemical Composition and Mechanical Properties, 10293, British Standard for EN, 2015.

14. Xu, Xiao-Lei, "Fracture Failure of A Diesel Engine Piston", Eng. Fail. Anal., (42), 2014, p.263-273

15. Wu, Maomeng \& Hao $\mathrm{Yu}$, "Research of 50Mn2V Continous Casting Slab Transverse Cracking during Its Retarded Cooling Process”, Eng. Fail. Anal., (30), 2013, p.61-73

16. Zhao, Huang $\mathrm{Yu}$, dkk, "Fatigue Life Analysis of Crawler Chain Link of Excavator", Engineering Failure Analysis, (79),2017, p.737-748.

17. C., Klinger \& Bettge D, "Axel Fracture Of An ICE3 High Speed Train", Eng. Fail. Anal., (35), 2013, p.66-81.

18. D., Brooksbank D \& Andrews KW, "Stress field around inclusions and their relation to mechanic properties", JISI (4) 1972, p.246-255 
